\title{
Endothelial cell loss and corneal thickness after intracapsular extraction and iris clip lens implantation: a randomised controlled trial (interim report)
}

\author{
H. CHENG, G. D. STURROCK, B. RUBinstein, AND C. J. BULPitT \\ From the Kent and Sussex Hospital, Tunbridge Wells
}

SUMmARY Patients in a randomised controlled trial were chosen either to have iris clip lens implantation after intracapsular cataract extraction or intracapsular extraction only. They were assessed in terms of corneal thickness, postoperative epithelial oedema, and endothelial cell counts. All patients had 1 eye submitted to operation, which was carried out by the same surgeon. There was significantly greater increase in corneal thickness $(P<0.05)$ on the 5 th postoperative day in eyes which had lens implants ( 23 patients with intracapsular extraction and 19 with implant), but the difference between the 2 groups became insignificant at 1 month (17 patients in each group).

Daily corneal thickness measurements and observations of epithelial oedema in a subgroup (20 patients divided equally into 2 groups) showed that postoperatively there was greater and more widespread corneal oedema after implant surgery. When the operated eye was compared with the unoperated eye, endothelial cell loss was significantly greater in those with implants $(P<0.01)$ than in those with simple intracapsular extraction.

Intraocular lens implantation after cataract extraction has regained general acceptance and is now widely practised. The reported incidence of various complications differs considerably, but the incidence of intractable corneal oedema would seem to be greater than expected from simple cataract extraction. This is also a complication which may be related to the trauma of additional steps entailed in implant surgery. Binkhorst and Leonard (1967) reported initial results in 124 eyes, treated over a period of 7 years and did not observe a single case of intractable corneal oedema. Jardine and Sandforth-Smith (1974) had reported an incidence of $10 \%$ in 70 cases. Pearce (1972, 1975), Jaffe and Duffner (1976), and Duffner $e$ t al. (1976) have reported an incidence of between 1.5 and $3.6 \%$ of serious corneal oedema. Pearce (1975) also reported an incidence of $13.2 \%$ of minor oedema which had not interfered with vision in the eyes studied.

When endothelial function is impaired, the corneal stroma may swell, with a resultant increase in thickness which may have no effect on vision until it exceeds 30\%. Miller and Dohlman (1970) have reported a permanent increase in corneal thickness

Address for reprints: H. Cheng, FRCS, Oxford Eye Hospital, Walton Street Oxford. in patients after simple intracapsular cataract extraction. Giardini and Cambiaggi (1956) have reported prolonged thickening of the cornea after similar types of surgery. Wood and Maumenee (1975), studying patients operated on by more modern techniques, did not support the findings of Miller and Dohlman, which suggests that modern techniques perhaps cause less trauma to the endothelium. Cheng et al. (1977) have compared corneal thickness of eyes after lens implantation and after intracapsular extraction in a retrospective study, and no significant difference was found in corneal thickness between these two groups.

The purpose of this study was to compare two groups of patients in whom 1 eye was submitted to surgery and was randomly chosen to have either simple intracapsular extraction or iris clip lens implant after intracapsular extraction. Three measures were chosen for assessment: (1) Central corneal thickness, (2) epithelial oedema in the immediate postoperative period, (3) endothelial cell counts.

\section{PATIENTS}

All patients had uncomplicated senile cataracts. They were randomly allocated to one or other type of surgery. The age of the patients ranged from 55 to 84 . 
EXCLUSION CRITERIA

Patients were excluded if they had corneal dystrophy or marked guttata, a previous history of iritis, a retinal hole or previous detachment, glaucoma, juvenile onset diabetes, myopia $>7$ dioptres, or a shallow anterior chamber.

\section{Methods}

Microsurgical techniques were used for all operations, which were carried out by one of the authors (H.C.). At the time of the evaluation of this study his experience consisted of having carried out over 100 operations of iris clip lens implant following cataract extraction as a primary procedure. Eighty-six of the first $\mathbf{1 0 0}$ patients had been followed up for 6 months to 3 years, and their visual results are presented in Fig. 1.

TYPE OF IMPLANT

The Federov implant (Rayners and Keelers Ltd), with a cruciate arrangement of loops, or a modified iridocapsular lens of Binkhorst type was used (Fig. 2). The latter has an anterior peg made of Supramid,

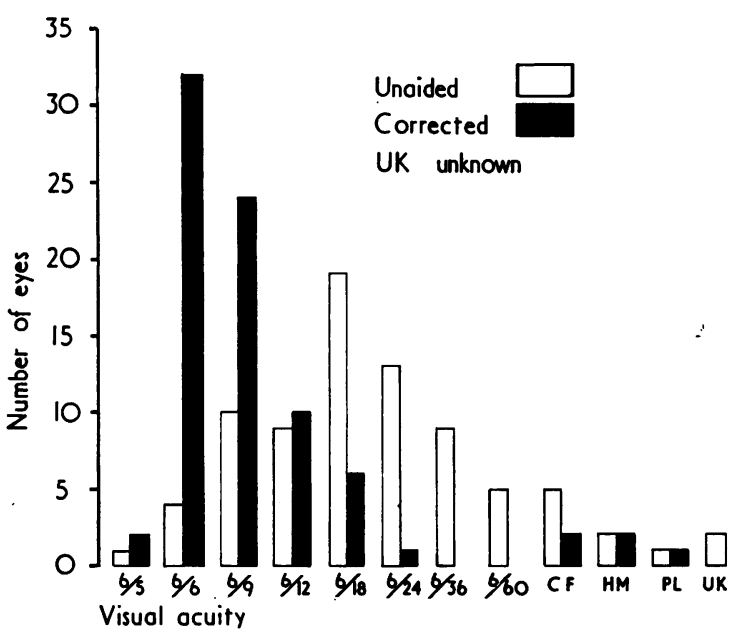

Fig. 186 Patients (86 eyes) with follow-up of 6 months to 3 years ( 2 patients lost to follow-up)
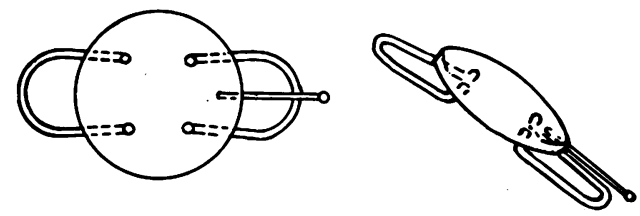

Fig. 2 Iridocapsular lens with antero-superior peg

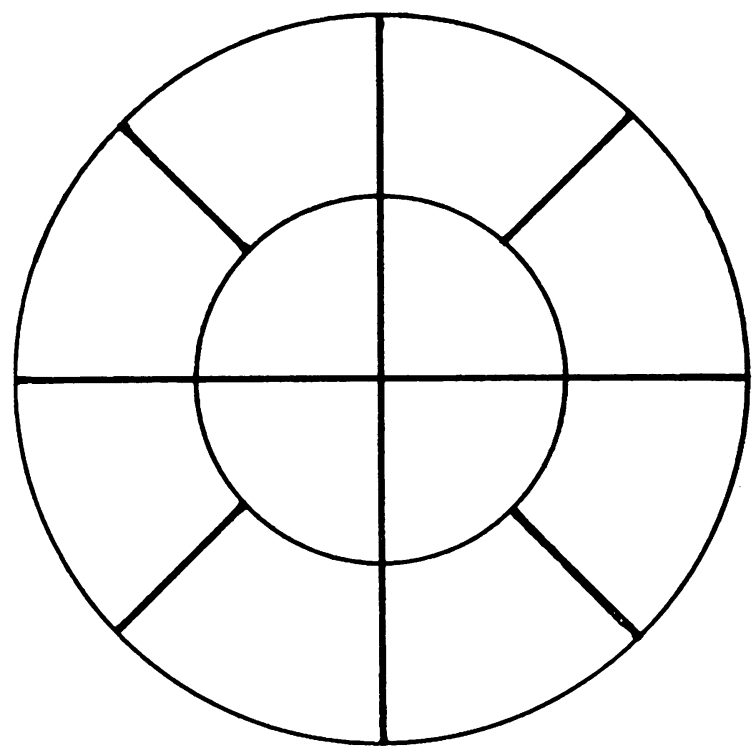

Fig. 3 Schematic division of cornea into 12 sections

which can be fastened to the supero-posterior loop through the peripheral iridectomy and was a modification by one of us (H.C.).

TECHNIQUE

Corneal thickness. The Haag-Streit 900 Pachometer was used for all measurements. The Mishima modification was not used, but patients who could not fix steadily on a point source of light were excluded. A minor modification used in a previous study (Cheng et al., 1977) was used, and the procedure was the same to ensure that the axial corneal thickness was measured. Both eyes of all patients were measured preoperatively and likewise at 5 days and 1 month postoperatively; 23 patients with intracapsular extraction and 19 with implants had measurements on the fifth day, and there were 17 patients in each group at 1 month. Twenty patients in the series had daily measurements from the preoperative day to the day when the corneal thickness of the operated eye became the same as the unoperated eye or when the patient had to be discharged because there was no reason to warrant his further stay in hospital. Ten of these patients had an implant in 1 eye, and the other 10 had simple intracapsular extraction in 1 eye.

\section{EPITHELIAL OEDEMA}

The cornea was divided into 12 sectors (Fig. 3). The number of sectors covered by epithelial oedema was recorded daily. Oedema confined to the wound edge was not included. 
ENDOTHELIAL CELL COUNT

The same 20 patients with daily measurements had endothelial cell photographs. The specular microscope, with a camera attachment, was devised by Sturrock and Sherrard and was based on a principle of Maurice (1968). Ten photographs were taken of the endothelium of each eye at each photographic session; the mean cell count was measured. In 11 of the 20 patients there were pre- and postoperative photographs, but postoperative photographs only were obtained in 9 patients. Where there were preoperative photographs the percentage cell loss was taken to be the difference between the pre- and postoperative counts of the same eye. Where there were postoperative photographs only, the cell loss was taken to be the difference between the operated and unoperated eyes. The method of counting is described by Sturrock and Sherrard (in press).

\section{IMPLANT - ENDOTHELIUM CONTACT}

At the time of surgery the amount of contact was graded as 'considerable', 'moderate', or 'slight'. 'Considerable' was defined as a situation where the implant slid against the cornea during insertion or intracameral manipulation; 'moderate' where the cornea rested on the implant for more than 30 seconds or where there were up and down movements of the cornea against the implant; and 'slight' where the implant briefly touched the endothelium.

\section{Results}

CORNEAL THICKNESS

Table 1 includes the number of patients who had measurements on the fifth postoperative day and at 1 month. The mean increase in corneal thickness at 5 days was greater in eyes with implants than in those which had only a simple intracapsular extraction. The difference was statistically significant $(P<0 \cdot 05)$. At 1 month the mean increase in corneal thickness was not significantly different when the 2 groups were compared.

Table 1 Increase in corneal thickness in the operated eyes

\begin{tabular}{|c|c|c|c|c|}
\hline $\begin{array}{l}\text { Time of } \\
\text { measurement }\end{array}$ & $\begin{array}{l}\text { Intracapsular } \\
\text { extraction }\end{array}$ & & Implants & \\
\hline & $\begin{array}{l}\text { Mean increase } \\
(\mathrm{mm})\end{array}$ & Variance & $\begin{array}{l}\text { Mean increase } \\
(\mathrm{mm})\end{array}$ & Variance \\
\hline \multirow{2}{*}{$\begin{array}{c}\text { 5th day } \\
\text { postop. }\end{array}$} & 0.0417 & 0.0018 & 0.0750 & 0.0032 \\
\hline & \multicolumn{4}{|c|}{$P<0.05$} \\
\hline \multirow{2}{*}{$\begin{array}{l}1 \text { month } \\
\text { postop. }\end{array}$} & 0.0219 & 0.0005 & 0.0145 & 0.0007 \\
\hline & \multicolumn{4}{|c|}{ Not significant } \\
\hline
\end{tabular}

$n=$ number of eyes

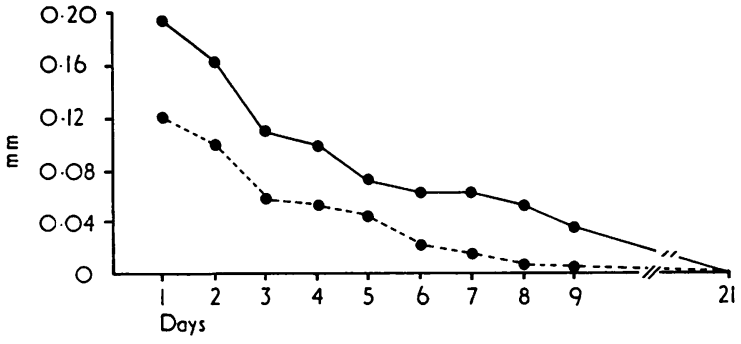

Fig. 4 Mean difference in corneal thickness between operated and unoperated eyes. Day $1=1$ st postoperative day. _-Implants. ----- Intracapsular extraction only

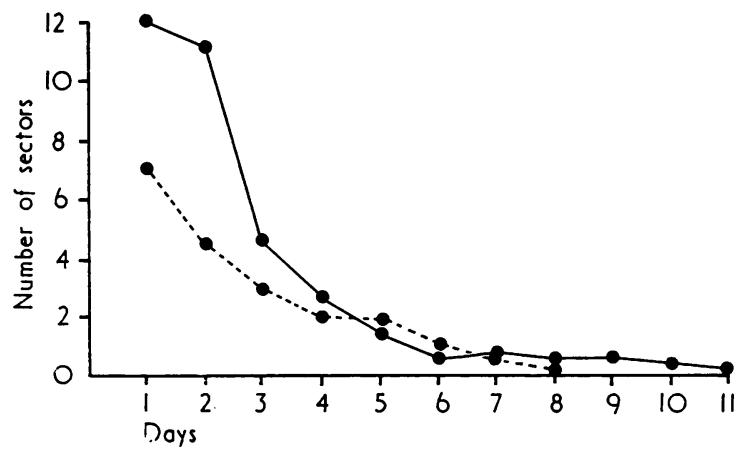

Fig. 5 Epithelial oedema. Number of sectors $=$ Number of sectors covered by oedema in all eyes in group/Number of eyes in that group. Day $1=1$ st postoperative day. Implants. ----- Intracapsular extraction only

Among the 20 patients with daily observations the mean difference in corneal thickness between the operated and unoperated eyes for the two groups are plotted in Fig. 4. There was greater increase in corneal thickness, which also lasted longer, in eyes with implants. The thickness values returned to normal for all operated eyes by 3 weeks.

\section{EPITHELIAL OEDEMA}

In the same 20 patients all implanted eyes had overall epithelial oedema on the first postoperative day compared to only 3 eyes after simple intracapsular extraction. Fig. 5 shows the mean number of sectors covered by epithelial oedema. There was a significant increase in the number of sectors involved in eyes with implants in the first 2 days $(P<0.01)$, but there was no significant difference by the third postoperative day. Two eyes in each group had raised intraocular pressure on the first day, but all eyes were normotensive by the second day.

ENDOTHELIAL CELL COUNT

There were photographs of 31 unoperated eyes (22 eyes of 11 patients with preoperative photographs 
plus 9 eyes of the other patients with postoperative photographs only). The cell counts ranged from 1591 to $3579 / \mathrm{mm}$. The difference in cell counts between the 2 eyes preoperatively and between the same unoperated eye pre- and postoperatively did not exceed $11 \%$ in any patient. The mean difference was $2 \cdot 7 \%$.

The cell loss for individual patients is listed in Table 2 for eyes with implants, and in Table 3 for those after intracapsular extraction. A number of patients developed complications which were listed against the initials of the patients. No surgical intervention was required for any of the complications.

The mean cell loss for the overall group of patients in the implant series was $41.3 \%$, and for the intracapsular extraction series $21.4 \%$ (Table 4). If those eyes which had complications were eliminated from the series the percentage loss was virtually unchanged for those with implants but dropped to $14.5 \%$ for those which had intracapsular extractions only.

Table 5 shows the mean difference in cell counts between the right and left eyes in the 2 groups postoperatively. The comparison between the implanted eyes and those which had simple cataract extraction was statistically significant $(P<0.01)$.

The amount of contact between the implant and

Table 2 Endothelial cell loss compared with increased corneal thickness and trauma at operation (implanted eyes)

\begin{tabular}{|c|c|c|c|c|c|c|}
\hline \multirow[b]{2}{*}{ Case } & \multirow{2}{*}{$\begin{array}{l}\% \\
\text { cell } \\
\text { loss } \\
\text { (or gain) }\end{array}$} & \multirow{2}{*}{$\begin{array}{l}\% \\
\text { increase } \\
\text { in } \\
\text { thickness }\end{array}$} & \multicolumn{3}{|c|}{$\begin{array}{l}\text { Contact between implant } \\
\text { and endothelium }\end{array}$} & \multirow{2}{*}{ Complications } \\
\hline & & & $\begin{array}{l}\text { Con- } \\
\text { siderable }\end{array}$ & $\begin{array}{l}\text { Moder- } \\
\text { ate }\end{array}$ & Slight & \\
\hline 1 & $63 \cdot 4$ & 56 & & + & & \\
\hline 2 & $62 \cdot 0$ & 46 & & + & & $\begin{array}{l}\text { Large tear of } \\
\text { Descemet } \\
\text { (from } \\
\text { section) }\end{array}$ \\
\hline 3 & $53 \cdot 6$ & 33 & & + & & \\
\hline 4 & $53 \cdot 0$ & 46 & + & & & $\begin{array}{c}\text { Pupil block } \\
\text { glaucoma } \\
\text { (relieved by } \\
\text { pupil diln.) }\end{array}$ \\
\hline 5 & $51 \cdot 0$ & 41 & & + & & \\
\hline 6 & $40 \cdot 7$ & 22 & + & & & \\
\hline 7 & $40 \cdot 0$ & 60 & + & & & \\
\hline 8 & $29 \cdot 0$ & $40 \cdot 5$ & & & + & \\
\hline 9 & $19 \cdot 5$ & 27 & & & + & \\
\hline 10 & +0.1 & 50 & & & + & $\begin{array}{l}\text { Late shallow- } \\
\text { ing of ant. } \\
\text { chamber }\end{array}$ \\
\hline
\end{tabular}

the endothelium is given in Table 2 . It shows that the 3 eyes with only 'slight' contact had the least cell loss. There was no close agreement between 'considerable' and 'moderate' contact and cell loss.

\section{PERCENTAGE INCREASE IN CORNEAL}

THICKNESS

The peak increase in corneal thickness was compared

Table 3 Endothelial cell loss compared with increase in corneal thickness (intracapsular extraction)

\begin{tabular}{llll}
\hline Case & $\begin{array}{l}\text { \% cell loss } \\
\text { (or gain) }\end{array}$ & $\begin{array}{l}\text { \% increase in } \\
\text { thickness }\end{array}$ & Complications \\
\hline 11 & 12.7 & 30 & \\
12 & 11.8 & 30 & \\
13 & 15.7 & 15 & \\
14 & 2.5 & 18 & 20 \\
15 & +0.3 & 51 & $\begin{array}{c}\text { Leucocytes on endo- } \\
\text { thelium vitreous in } \\
\text { wound }\end{array}$ \\
16 & 66.8 & 48 & $\begin{array}{c}\text { Hypopyon and late } \\
\text { choroidal detach- } \\
\text { ment }\end{array}$ \\
17 & 44.5 & 10 & $\begin{array}{c}\text { Pupil block glaucoma } \\
\text { (relieved by diln.) }\end{array}$ \\
18 & +0.5 & 5 & $\begin{array}{c}\text { Loss of AC } \\
\text { (3 to 8 hours) }\end{array}$ \\
\hline
\end{tabular}

Table 4 Mean endothelial cell loss and mean peak increase in corneal thickness

\begin{tabular}{llll}
\hline & Category & $\begin{array}{l}\% \text { mean cell } \\
\text { loss }\end{array}$ & $\begin{array}{l}\text { Mean \% peak } \\
\text { increase in } \\
\text { thickness }\end{array}$ \\
\hline Overall group & $\begin{array}{l}\text { Implants } \\
\text { (10 eyes) } \\
\text { Intracapsular } \\
\text { extraction } \\
\text { (10 eyes) }\end{array}$ & 41.3 & 42.1 \\
\hline No complications & $\begin{array}{l}\text { Implants (7 eyes) } \\
\text { Intracapsular } \\
\text { extraction } \\
\text { (6 eyes) }\end{array}$ & 14.6 & 27.8 \\
\hline
\end{tabular}

Table 5 Endothelial cell count-difference between 2 eyes (all patients had surgery to 1 eye only)

\begin{tabular}{lll}
\hline & $\begin{array}{l}\text { Intracapsular } \\
\text { extraction }\end{array}$ & Implants \\
\hline No. of patients & 10 & 10 \\
Mean difference in cell count $/ \mathrm{mm}^{2}$ & 381 & 928 \\
$\mathbf{P}<0.01$ & & \\
\hline
\end{tabular}


with the preoperative value and expressed as a percentage $(100 \%=$ preoperative value). With one exception the greatest corneal thickness occurred on the first postoperative day. Tables 2 and 3 show the percentage increase in thickness for each patient, and Table 4 shows the mean percentage increase for the overall groups as well as for those without complications.

\section{Discussion}

Cheng et al. (1977) in a retrospective study did not find any significant difference between the corneal thickness of eyes which had simple uncomplicated intracapsular extractions and iris clip lens implants. The patients studied had follow-up periods from 6 months to 4 years. This suggested that up to that time no decompensation had occurred in these eyes. However, in the present prospective study on larger numbers of patients there was a significant increase in corneal thickness on the fifth postoperative day in those eyes which had lens implants, which suggests that there is a significantly greater amount of endothelial injury after this type of operation. This finding is supported by the daily measurements of corneal thickness and epithelial oedema in a subgroup of patients, showing that corneal oedema is greater and more widespread in eyes after implant surgery. These findings correlate well with the amount of endothelial cell loss, which is significantly greater after lens implantation. The apparently close correlation between percentage increase in corneal thickness and percentage cell loss would suggest that 'functional impairment' bears a relationship with cellular depletion. However, the numbers studied were small, and when individual eyes were considered the relationship was less close than the mean values suggested. This would be in accord with our knowledge of hydration of the cornea, which depends on many factors (Mishima, 1968). The percentage cell loss both for eyes with implants and for those with simple extractions are in accord with those reported by Bourne and Kaufman (1976a, b) and Forstot et al. (1977). Though our number was small, it is interesting to note that the 3 implanted eyes with the least cell loss were recorded at operation to have only 'slight' contact between the lens and the endothelium. This could be explained by the work of Kaufman and Katz (1976), who showed that endothelial cells may be ruptured on contact with the methyl methacrylate implant. However, other factors can clearly cause endothelial cell loss. In our cases which had only simple intracapsular extraction there were 3 cases with a large percentage cell loss. Of the 3,1 had no obvious cause. One had apparently abnormal cells with adherent leucocytes in the endothelial photographs and could have been abnormally susceptible to injury; he also had a knuckle of vitreous embedded in the wound postoperatively, although there was no vitreous loss at operation. Therefore, he could have had, in addition, an event leading to vitreous extrusion. The third patient had a hypopyon iritis, and her cell loss could have been due to inflammation.

At present there is no knowledge of the minimum number of endothelial cells required for healthy function of the cornea. Furthermore, present methods enable cell counts to be made only of a small axial area and may not be entirely representative of the counts in the corneal periphery. It is important to note that even when there is a reported cell loss of $80 \%$ the cornea may stay perfectly transparent and there is no increase in corneal thickness (Laing et al., 1976b). Thus, the mere number of cells can be only one of many factors in maintaining normal corneal function. The work of Bourne and Kaufman (1976a, b) and Laing et al. (1976a) as well as of Sturrock and Sherrard (in press) would suggest that there is a gradual drop-out with age as well as with intraocular inflammation (Sturrock, personal communication). Therefore, the more widespread endothelial injury and the greater cell depletion after lens implantation would imply a lowering of endothelial reserve. Since lens implantation is now more widely practised, it is important for surgeons doing this operation to bear in mind the possible harm that may be inflicted and to take the utmost care to protect the endothelium during surgery.

We thank Mrs J. Cotton for her voluntary secretarial help, Miss P. Clifton for data handling, and the Knoop Trust for financial help.

\section{References}

Binkhorst, C. D., and Leonard, P. A. M. (1967). Iris-clip pseudophakos implantation. American Journal of Ophthalmology, 64, 947.

Bourne, W. M., and Kaufman, H. E. (1976a). Corneal endothelium in vivo. American Journal of Ophthalmology, $81,319$.

Bourne, W. M., and Kaufman, H. E. (1976b). Endothelial damage associated with intraocular lenses. American Journal of Ophthalmology, 81, 482.

Cheng, H., James, A., and Rubinstein, B. (1977). Corneal oedema-iris-clip implantation and simple intracapsular extraction compared. Ophthalmic Surgery, 8, 64.

Duffner, L. R., Wallace, K. W., and Stiles, W. R. (1976). Copeland intraocular lens. American Journal of Ophthalmology, 82, 590.

Forstot, S. L., Blackwell, W., Jaffe, N. S., and Kaufman, H. E. (1977). Transactions of the American Academy of Ophthalmology and Otolaryngology, 83, 195.

Giardini, A., and Cambiaggi, A. (1956). Recherches sur 
l'épaisseur cornéenne après extraction de la cataract. Ophthalmologica, 131, 44.

Jaffe, N. S., and Duffner, L. R. (1976). The iris-plane (Copeland) pseudophakos implantation. American Journal of Ophthalmology, 64, 947.

Jardine, P., and Sandford-Smith, J. H. (1974). Federov iris-supported intraocular acrylic lens. British Journal of Ophthalmology, 58, 718.

Kaufman, H. E., and Katz, J. I. (1976). Endothelial damage from intraocular lens insertion. Investigative Ophthalmology, 15, 996.

Laing, R. A., Sandstrom, M. M., Berrospi, A. R., and Leibowitz, H. M. (1976a). Changes in the corneal endothelium as a function of age. Experimental Eye Research, 22, 587.

Laing, R. A., Sandstrom, M., Berrospi, A. R., and Leibowitz, H. M. (1976b). Morphological changes in corneal endothelial cells after penetrating keratoplasty. American Journal of Ophthalmology, 82, 459.
Maurice, D. M. (1968). Cellular membrane activity in the corneal endothelium of the intact eye. Experientia, 24, 1094.

Miller, D., and Dohlman, C. H. (1970). Effect of cataract surgery in the cornea. Transactions of the American Academy of Ophthalmology and Otolaryngology, 74, 369.

Mishima, S. (1968). Corneal thickness. Survey of Ophthalmology, 13, 57.

Pearce, J. L. (1972). Long-term results of the Binkhorst iris-clip lens in senile cataract. British Journal of Ophthalmology, 56, 324.

Pearce, J. L. (1975). Long-term results of the Choyce anterior chamber lens implants. British Journal of Ophthalmology, $59,101$.

Sturrock, G. D., and Sherrard, E. (in press).

Wood, W. J., and Maumenee, A. E. (1975). Corneal thickness after cataract surgery. Transactions of the American Academy of Ophthalmology and Otolaryngology, 79, 631. 